\title{
МЕЖДУНАРОДНО-ПРАВОВЫЕ СРЕДСТВА ПРОТИВОДЕЙСТВИЯ ЛЕГАЛИЗАЦИИ (ОТМЫВАНИЮ) ДОХОДОВ, ПОЛУЧЕННЫХ НЕЗАКОННЫМ ПУТЕМ
}

\author{
Л.Н. Анисимов
}

В последнее десятилетие организованная преступность и коррупция, в том числе легализация (отмывание) доходов, полученных незаконным путем, приняли международный характер, в особенности в крупных финансовых и экономических центрах Европы, и превратились в политический фактор, негативно влияющий на авторитет государственной власти в ряде стран, в том числе в Российской Федерации.

Абсолютным большинством государств Европы, да и всем международным сообществом признано, что легализация (отмывание) денег и имушества, полученных преступным или незаконным путем, стала глобальной угрозой экономической безопасности государств, что требует принятия согласованных мер как на национальном, так и на европейском и международном уровнях для защиты легальной экономики от криминальных инвестиций.

Объективности ради отметим, что первыми к пониманию необходимости организации борьбы с отмыванием незаконно полученных денег пришли законодатели Соединенных Штатов. Конгресс США еще в 1970 г. принял закон о банковской тайне, обязывающий финансовые и некоторые другие учреждения противодействовать легализации доходов, полученных преступным путем. В 1986 г. американские законодатели включили в Свод законов (раздел 18) статью 1956, квалифицирующую отмывание денег как преступное деяние и предусматривающую максимальное наказание за него в виде 20 лет тюремного заключения и штрафа в 500 тыс. долларов ${ }^{2}$. Аме-

Доктор юридических наук, профессор кафедры международного права МГИМО (У) МИД РФ.

' О происхождении этого понятия см.: Филатов В.П. Правовые аспекты борьбы с международной преступностью // Московский журнал международного права, 1997, № 4, с. 64.

${ }^{2}$ См.: Кузнечов Н. Ф.. Багаутоинова С.К. Контроль над легализаиией преступных доходов в США // Вестник Московского университета. Серия 11: Право. 1997, № 6, c. 39. 
риканцы перманентно принимали различные нормативно-правовые акты в этой сфере, и специалисты считают США «самой активной страной, борющейся с отмыванием грязных денег» ${ }^{3}$.

Как считают специалисты, в мире ежегодно отмывается не менее 200 миллиардов долларов. Преимущественно это доходы транснациональных преступных корпораций, получаемые от незаконного оборота наркотиков, сокрытия прибыли, торговли оружием, а также в результате других преступлений.

Располагая этими колоссальными средствами, организованные преступные группировки получают безграничные возможности подкупа, коррупции и террора. Именно поэтому они представляют серьезную угрозу законности, общественному порядку и эффективной деятельности правительств. В то же время именно огромный объем находящихся в незаконном обороте денежных средств вынуждает руководителей преступных организаций (синдикатов) так или иначе использовать легальную экономику и финансовую систему для отмывания грязных денег, что составляет уязвимое звено преступной деятельности, облегчая государствам контроль над потоками незаконных денежных средств, их изъятие и конфискацию.

Важным средством борьбы с организованной преступностью является международно-правовое сотрудничество государств.

Международно-правовые нормы противодействия легализации доходов, полученных незаконным (преступным) путем

Мировым сообществом накоплен определенный межгосударственный опыт борьбы с отмыванием денег и другого имущества, полученного незаконным путем, и разработана общая международноправовая концепция противодействия легализации нелегальных доходов, нашедшая свое отражение в таких важнейших международноправовых документах, как Конвенция ООН о борьбе против незаконного оборота наркотических средств и психотропных веществ 1988 г. (Венская конвенция) ${ }^{4}$ и Конвенция Совета Европы об отмы-

'Там же, c. 46.

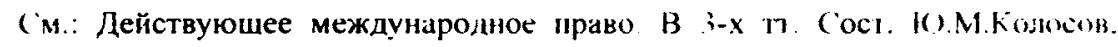
7.С.Кривчикова. Т З. М.. 1997, с. 60.89. 
вании, выявлении, изъятии и конфискации доходов от преступной деятельности 1990г. (Страсбургская конвенция) ${ }^{5}$.

Прежде всего обозначим положения Венской конвенции в части, касающейся рассматриваемого нами вопроса. Правда, в ней не используется термин «отмывание денег» и говорится не о «преступных доходах», а о доходах, полученных от незаконного оборота наркотических средств и психотропных веществ. При этом согласно п. «р» ст.1 ««доходы» означают любую собственность, полученную или приобретенную прямо или косвенно в результате совершения правонарушения, признанного таковым в соответствии с пунктом 1 статьи 3», а под собственностью согласно п. «q» ст. 1 понимаются «активы любого рода, материальные или нематериальные, движимые или недвижимые, осязаемые или неосязаемые, а также юридические документы или акты, удостоверяющие право на такие активы или участие в них» ${ }^{6}$. В п.1 ст.3 установлено, что «каждая Сторона принимает такие меры, которые могут потребоваться, с тем чтобы признать уголовными преступлениями согласно своему законодательству следующие действия, когда они совершаются преднамеренно:...

- конверсию или перевод собственности. если известно, что такая собственность получена в результате любого правонарушеиия или правонарупений. признанных таковыми в соответствии с подпунктом (а) настоящего пункта, или в результате участия 6 таком правонарушении или правонарушениях, в челях сокрытия или утаивания иезаконного источника собственности или в челях оказаиия помочи любому личу. участвуючему в совершении такого правонаруиения или правонарушений, с тем чтобы он мог уклониться от ответственности за свои действия;

- сокрытие или утаивание подлинного характера, источника, местонахождения, способа распоряжения, перемешения, подлинных прав в отношении собственности или ее принадлежности, если известно, что такая собственность получена в результате правонарушения или правонарушений, признанных таковыми в соответствии с подпунктом (a) настоящего пункта, или в результате участия в таком правонарушении или правонарушениях",

'См.: Мсждународное частное право. Сборник документов. М., 1977, с. 744757; Сборник документов Совста Европы в области зациты прав человека " борьбы с преступностью. М., 1998, с. 168-184.

"Злесь и лалее цит. по: Действуюшее международное ираво. Т : с. 60 , 
a также, с учетом конституционных положений и основных принципов правовых систем государств-участников, - «приобретение, владение или использование собственности, если в момент ее получения было известно, что такая собственность получена в результате правонаруиения или правонаруиений, признанных таковыми в соответствии с подпунктом (a) настоячего пункта, или в результате участия в таком правонарушении или правонарушениях».

Как видим, в приведенных положениях речь идет о правонарушениях, а не о преступлениях. В этом есть определенный смысл. Согласно общим принципам международного права те или иные противоправные деяния могут не признаваться преступлениями в соответствии с национальным законодательством государства - участника того или иного международного правового акта. Государствоучастник Конвенции само определит, какую ответственность установить за то или иное правонарушение: уголовно-правовую, административную или гражданско-правовую. Например, во многих странах установлена уголовная ответственность за немедицинское употребление наркотических средств или психотропных веществ, а в иных такой ответственности нет, в частности в Российской Федерации. В Нидерландах же, к примеру, за изготовление и продажу наркотиков установлена административная ответственность, в то время как во многих странах мира подобные деяния наказываются смертной казнью.

Перечисленные в п. «а» ст.3 Конвенции правонарушения - это уголовные преступления в сфере незаконного производства и оборота наркотиков. Таким образом, уголовным правонарушением признается отмывание только тех доходов, которые получены в результате преступлений, связанных с наркотиками.

Кроме самих деяний, относящихся к отмыванию денег, государства-участники должны в соответствии с п.1 ст.3 Конвенции признать уголовными преступлениями, с учетом их конституционных положений и основных принципов правовой системы, также участие, причастность или вступление в преступный сговор с целью совершения любого из таких деяний, попытки совершить такие деяния, а также пособничество, подстрекательство, содействие или дачу советов при их совершении.

Иными словами, Конвенция дает развернутый перечень действий по отмыванию денег и их четкое юридическое определение: эти действия признактся умышленными (т.е. совершаемыми преднамс- 
ренно) уголовными преступлениями. При этом осознание, намерение или цель как составные элементы этих преступлений «могут быть установлены из объективных фактических обстоятельств дела» (п.3 ст.3).

Данное Венской конвенцией 1988 г. определение сущности совершаемых противоправных деяний получило широкое признание в международном праве, в том числе в европейском международном и национальном праве. При этом последующие международноправовые акты существенно конкретизировали и дополнили его. К таким актам относится прежде всего Конвенция об отмывании, выявлении, изъятии и конфискации доходов от преступной деятельности 1990 г. (Страсбургская конвенция), в самом названии которой уже используется формулировка «доходы от преступной деятельности», а в ст. 1 - «уголовное правонарушение, в результате которого получены доходы» ${ }^{7}$. Кроме того, в п.1 ст. 6, озаглавленной «Правонарушения, связанные с отмыванием средств», установлено, что каждая сторона принимает законодательные и другие необходимые меры, чтобы квалифицировать в качестве правонарушений следующие деяния, если они совершены умышленно:

«а) конверсию или передачу имущества, если известно, что это имущество является доходом, полученным преступным путем, с целью скрыть незаконное происхождение такого имущества или помочь любому лицу, замешанному в совершении основного правонарушения, избежать правовых последствий своих деяний;

b) утаивание или сокрытие действительной природы, происхождения, местонахождения, размещения или движения имущества или прав на него, если известно, что это имущество представляет собой доход, полученный преступным путем;

c) приобретение, владение или использование имущества, если в момент его получения было известно, что оно является доходом, добытым преступным путем;

d) участие или соучастие в любом из правонарушений, определенных в настоящей статье, или в покушении на его совершение, а также помощь. подстрекательство, содействие или консультирование в связи с совершением такого преступления».

Причем в п. 2 «а» ст. 6 специально оговорено - «не имеет значения, подпадает ли основное правонарушение под уголовную юрисдикции Стороны». Это положение вызывает неоднозначное толкова-

\footnotetext{
' Здесь и жалее иит по: Совет Европы и Россия М., 201)0, № 2, с. 3.3-42
} 
толкование со стороны некоторых специалистов, которые считают, что криминализация основного правонарушения не имеет значения для квалификации соответствующего деяния в качестве отмывания денег $^{8}$. Такой подход, на наш взгляд, не представляется достаточно обоснованным.

Страсбургская конвенция 1990 г. расширяет сферу уголовных правонарушений, являющихся источником преступных доходов, отмывание которых в свою очередь составляет преступление. В этих целях Конвенция вводит понятие «основное правонарушение». Согласно п.«е» ст. 1, оно означает любое уголовное правонарушение, в результате которого были получены доходы, которые могут стать предметом правонарушения в соответствии со ст. 6 Конвенции. Таким образом, в отличие от Венской конвенции, признающей основными правонарушениями только преступления в сфере оборота наркотиков, Страсбургская конвенция охватывает все уголовные преступления. При этом, однако, на основании п. 4 ст.6 за участниками Конвенции сохраняется право в момент подписания или при сдаче на хранение документов о ратификации сделать оговорку о том, на какие основные правонарушения или категории таких правонарушений они будут распространять положения Конвенции.

Конвенция Совета Европы об отмывании, выявлении, изъятии и конфискации доходов 1990 г., использующая, в отличие от Венской конвенции 1988 г., термин «отмывание доходов», шире определяет понятие «доход». В соответствии с п.«а» ст.1 он означает любую экономическую выгоду, полученную в результате совершения уголовного правонарушения. Эта выгода может включать любое имущество, определенное в п.«b» ст.1 (определение имущества соответсвует определению собственности по Конвенции 1988 г.).

Далее, Страсбургская конвенция содержит еще несколько важных положений, касающихся понятия отмывания доходов. В частности, в ст.І она прямо признает это правонарушение уголовным преступлением.

Исключительно важное значение придается идентификации личности и имущества, а также прозрачности кредитно-финансовой системы. Так, в ст.4 подчеркивается, что стороны не могут отказать-

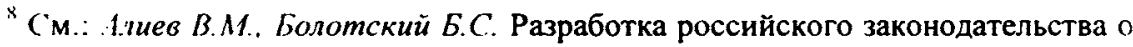
противодействии легализации (отмыванию) доходов, полученных незаконным путем. некотсрые дискуссионные вопросы // Государство и право, 1999, № 6 . $\therefore 4 i$ 
ся от наложения ареста на банковские, финансовые или коммерческие документы под предлогом банковской тайны. Наряду с этим каждой из сторон предлагается принять законодательные и другие меры, позволяющие применять специальные приемы расследования, облегчающие идентификацию и розыск доходов, а также сбор соответствующих доказательств.

Согласно п.2 «b» ст.6 Страсбургской конвенции, за ее участниками сохраняется право предусмотреть в национальном законодательстве, что преступления, представляющие собой отмывание доходов по п.l ст.6 Конвенции, не могут вменяться в вину лицам, совершившим основное правонарушение. Это положение является, несомненно, ограничительным, поскольку оно умаляет юридическое значение отмывания доходов как самостоятельного (хотя и связанного с основным правонарушением) уголовного преступления. При этом Конвенция, закрепляя указанную норму, не возлагает на государства каких-либо обязательств по усилению ответственности лица, если после совершения преступления оно отмывало доходы, полученные от этого деяния. Таким образом, указанное положение Конвенции позволяет преступнику полностью избежать ответственности за отмывание доходов, полученных в результате совершенного им преступления, и является препятствием для дальнейшего развития национального законодательства в области борьбы с легализацией преступных доходов.

И наконец следует отметить еще одну важную норму Страсбургской конвенции. Согласно п. 3 «а» ст.6 государства-участники могут признать преступными в соответствии с их национальным законодательством деяния по отмыванию денег, когда правонарушитель «должен был предполагать, что имущество является доходом, полученным преступным путем», т. е. действовал не только по умыслу, но и по неосторожности. Вопрос об ответственности за правонарушение, совершенное по неосторожности как форме вины, возникает прежде всего в том случае, когда речь идет об ответственности сотрудников банков и других финансовых учреждений, ведущих работу с клиентами и обязанных уделять особое внимание источнику происхождения денежных средств клиента. В соответствии с приведенным положением Страсбургской конвенции некоторые страны закрепили в национальном законодательстве ответственность за отмывание доходов по неосторожности.

Таким образом, Страсбургская конвенция содержит ряд существенных нововведений по сравнению с Венской конвснцией в опре- 
делении отмывания денег. Самым значительным из них, безусловно. является расширение сферы основных правонарушений на все уголовные преступления (с учетом возможных оговорок в соответствии с п.4 ст.6). Положения об этом отражают соответствующую тенденцию в международном сотрудничестве.

В июне 1991 г. Советом европейских сообществ (ЕС) был принят еще один документ - Директива Совета ЕС № 91/308 от 10 июня 1991 г. о воспрепятствовании использованию финансовой системы в целях легализации доходов от преступной деятельности.

В Директиве четко определено, что преступной является легализация не только доходов и имущества, полученных в результате торговли наркотиками, как это определяет Венская конвенция 1988 г., но и «имущественных ценностей всех видов (материальных и нематериальных, движимых и недвижимых), правовых титулов и документов, которые удостоверяют право собственности и иные имущественные права» ${ }^{9}$, если эти «экономические выгоды» получены в результате совершения любых деяний, признанных преступными на территориях государств-членов Совета Европы. Иными словами, то, что в одном государстве отмываемые доходы были получены в результате совершения уголовного правонарушения на территории другого государства, не влияет на юридическую квалификацию отмывания денег в качестве преступления по национальному законодательству первого государства.

Ст.1 Директивы устанавливает, что ее положения должны относиться ко всем кредитным и финансовым учреждениям, в том числе к страховым компаниям, и филиалам указанных учреждений, расположенных за пределами Европейского Союза, а также к тем предприятиям, организациям и профессиональным группам (казино, игорные заведения, пункты обмена валюты, нотариусы, адвокаты, налоговые консультанты и др.), которые могут быть использованы для отмывания капиталов.

Согласно абз.4 ст.1 Директивы ЕС 91/308 от 10 июня 1991 г., под легализацией незаконно приобретенных средств понимается конверсия или передача имущества, полученного незаконным путем, с целью скрыть незаконное происхождение такого имущества, утаивание или сокрытие действительной природы, происхождения, местонахо-

$\checkmark$ Здесь и далее иит. по: Council Directive 91/308/EES of 10 June 1991 on prevenlion of the use of the financial system for the purpose of money laundering. // Official Joumal, No 166, 28, 06/1991, p. 0077-0082. 
ждения, размещения или движения имущества или прав на него, если известно, что это имущество приобретено преступным путем, а также приобретение, владение и использование имущества, если в момент его получения известно, что оно является доходом, добытым преступным путем. Перечисленный перечень деяний является общим описанием объективной стороны состава рассматриваемого преступления.

Директива 91/308 согласно ст. 189 Договора об учреждении ЕЭС, в частности, является нормативно-правовым актом, обязательным для всех государств-участников в отношении достижения указанных в ней целей. При этом за ними сохраняется свобода принятия конкретных мер по ее выполнению.

Рассматриваемая Директива содержит программу действий в финансовой сфере, направленную на предотвращение легализации доходов и развитие сотрудничества финансовых учреждений и правоохранительных органов. Так, она возлагает на кредитные и финансовые институты следующие обязанности:

- осуществлять идентификацию клиентов и всех сделок на сумму, равную или превышаюшую 15 тыс. экю;

-- сохранять в течение определенного срока документы о банковских операциях;

- проверять финансовые сделки на предмет их возможной связи с отмыванием доходов;

- сообщать компетентным государственным органам о подозрительных финансовых операциях.

Введение обязанности идентификации клиентов, предусмотренное в ст. 3 Директивы, и обязанности хранения документов о финансовых операциях в течение пяти лет (ст. 4) имеет целью документальную фиксацию финансовых операций, позволяющую при проведении расследования преступлений в сфере отмывания денег восстановить всю цепочку движения легализуемых средств.

Статья 5 Директивы обязывает кредитные и финансовые учреждения особенно внимательно проверять операции, которые, по их мнению, могут быть связаны с отмыванием денег. С точки зрения исследователей ${ }^{10}$, юридическое содержание этой нормы представляется недостаточно определенным.

10 См., например: Нванов Э.А. Отмывание денег и правовое регулирование борьбы с ним. М., 1999, с. 43. 
Из обязанности осуществления проверки логично вытекает требование о сообщении компетентным государственным органам о подозрительных операциях. В соответствии с положениями Директивы (статьи 6 - 9), государства должны обязать кредитные и финансовые учреждения сообщать о всех ситуациях, имеющих признаки отмывания денег. В случае, если есть серьезное подозрение или информация о том, что финансовая операция связана с легализацией незаконных доходов, эти учреждения не должны осуществлять ее до того, как сообцат о ней компетентным органам. По решению последних подозрительная финансовая операция может быть приостановлена. При этом вопрос о процедуре и сроке приостановления отнесен Директивой на усмотрение государств.

В соответствии со ст. 8 Директивы клиенту не должно сообщаться о приостановлении его финансовой операции, а также о том, что о ней были проинформированы органы по борьбе с отмыванием денег. Финансовые и кредитные учреждения освобождаются от ответственности за передачу информации в случае, если подозрение в легализации доходов не подтвердилось.

Важное значение для сотрудничества финансовых институтов и компетентных органов имеет решение вопроса об использовании предоставленной информации о подозрительных финансовых операциях. Директива рекомендует предусмотреть применение этих сведений только в целях борьбы с отмыванием денег. Однако данный вопрос отнесен на усмотрение государств, которые могут согласно ч. 3 ст. 6 Директивы разрешить уполномоченным органам распоряжаться этой информацией и в других целях. На наш взгляд, для более эффективного сотрудничества правоохранительных органов с кредитными и финансовыми учреждениями целесообразно ограничение использования информации, поскольку отсутствие таких ограничений, означающее широкое применение конфиденциальных данных, относящихся к банковской тайне, способно нанести серьезный ущерб авторитету банков и других кредитных и финансовых институтов.

Таким образом, в основе установленной Директивой системы конкретных мер по предотвращению отмывания денег в государствах-членах лежит тесное сотрудничество их финансовых и кредитных учреждений со специальными органами по противодействию легализации преступных доходов. 
Имплементация положений Директивы в государствах ЕС стала предметом двух докладов ${ }^{1}$, представленных Еврокомиссией на рассмотрение в Совет ЕС и Европарламент. Оба доклада, подготовленные соответственно в 1995 и в 1998 гг., констатируют, что все государства-члены ЕС надлежащим образом осуществили имплементацию Директивы в национальном законодательстве. При этом подчеркивается, что цели, определенные в Директиве, были в основном достигнуты.

Вместе с тем указывается, что по прошествии нескольких лет с момента принятия Директивы изменился характер преступлений, связанных с легализацией (отмыванием) денежных средств и других капиталов, способы, методы и средства их осуществления. Отмывание денег как динамично развивающаяся криминальная деятельность со временем охватило не только сферу банковского капитала, но и многие отрасли экономики, а также некоторые иные сферы деятельности, не охваченные регулированием Директивы. Это поставило на повестку дня вопрос о внесении в нее определенных изменений и дополнений.

В соответствии с рекомендациями, данными Советом ЕС и Европарламентом после рассмотрения второго доклада, Еврокомиссия в 1998 г. начала работу по составлению проекта изменений и дополнений к Директиве 1991 г., который был представлен в конце 1999 г. в Совет ЕС и Европарламент.

Основное нововведение, содержащееся в проекте, состоит в распространении обязанности сообщать о подозрительных операциях на широкий круг учреждений и организаций, которые находятся за пределами финансового сектора экономики и в той или иной степени могут вовлекаться в процессы, связанные с отмыванием денег. $\mathrm{K}$ таким учреждениям относятся, например, казино, риэлторские компании, ювелирные салоны, аукционы, нотариальные конторы, адвокатские бюро и др. Другое важное дополнение состоит в расширении сферы основных правонарушений.

\footnotetext{
"First Commission Report to the European Parliament and the Council on the implementation of the Money Laundering Directive, 1995; Second Commission Report to the European Parliament and the Council on the implementation of the Money Laundering Directive, 1998.
} 
Международное сотрудничество государств в борьбе с отмыванием капиталов

Сотрудничество государств Европы в противодействии легализации (отмыванию) денежных средств и других доходов, полученных незаконным путем. осуществляется как на основе общих норм и принципов международного права, так и в рамках так называемого европейского права ${ }^{12}$. В настоящее время европейским правом пользуются государства, юридические и физические лица, так или иначе вовлеченные в отношения с участием Совета Европы, европейских сообществ и Европейского Союза, а также многих других международных организаций. В европейском праве гармонично сочетаются идеи и нормы континентального и общего права, принципы равенства сторон и национального суверенитета. Для него характерна согласованность, с одной стороны, с общим международным правом, a c другой - c национальным правом. К примеру, в рамках правового сотрудничества государств-участников Совета Европы по его рекомендации проводятся унификация их законодательства и правовой политики и соответствующие реформы. В этих целях функционируют два органа - Европейский комитет правового сотрудничества (гражданское, коммерческое, административное и международное право) и Европейский комитет по вопросам преступности (уголовное право, криминология, психология), которому оказывает содействие Научно-криминологический совет.

Европейский Союз ставит своей целью интеграцию прежде всего в сфере базисных общественных отношений - экономических, что, разумеется, требует повышения эффективности сотрудничества в борьбе с экономическими преступлениями, в том числе и с отмыванием капиталов, полученных незаконным путем.

Рассмотренные выше международно-правовые документы и другие общие международные и европейские нормативно-правовые акты по борьбе с отмыванием доходов предопределяют необходимость организационно-правового международного сотрудничества по трем основным направлениям:

12 Подробнее см., например: Топорнин Б.Н. Европейское право. Учебник. М., 1999; Саидов A.X. Концепция европейского правового пространства: проблемы и перспективы // Московский журнал международного права, 1992, № 3, с. 5972. 
- сближение позиций по уголовно-правовой оценке отмывания капиталов (доходов) в законодательстве государств-участников;

- унификация внутригосударственных мер, направленных на борьбу с легализацией (отмыванием) денежных средств или иных капиталов, полученных незаконным путем;

- определение наиболее эффективных форм и процедур международного сотрудничества в борьбе с отмыванием доходов.

Так, статьи 2 и 3 Страсбургской конвенции обязывают ее участников принять законодательные и иные необходимые меры, позволяющие проводить расследование преступлений, связанных с отмыванием доходов, осуществлять их розыск и конфискацию при условии их криминального происхождения.

Учитывая, что их принятие тесно связано с существующими в государствах концепциями прав человека, а также серьезно затрагивает финансовые и банковские системы государств, Конвенция оставляет на усмотрение сторон выбор необходимых конкретных мер. При этом она обязывает ее участников предоставлять их судам или другим компетентным органам право издавать постановления о предъявлении или аресте банковских, финансовых или коммерческих документов в целях осуществления соответствующих мер. При этом оговаривается, что государства не могут уклоняться от исполнения этой обязанности, ссылаясь на необходимость сохранения банковской тайны.

Кроме того, Страсбургская конвенция содержит рекомендательный перечень специальных приемов расследования, облегчающих идентификацию и розыск доходов, а также сбор соответствующих доказательств. Согласно п.2 ст.4, это установление негласного контроля за счетами, ведение наблюдения, перехват сообщений, доступ к компьютерным системам и постановления о предъявлении определенных документов.

Помимо мер, принимаемых на национальном уровне, Страсбургская конвенция регламентирует различные формы и процедуры международного сотрудничества. К ним относятся обмен информацией, предоставление помощи в проведении расследований и судебных разбирательств, принятие предварительных мер и конфискация имущества и доходов от преступной деятельности, выдача преступников, различные формы технического сотрудничества, процедура направления запросов об оказании юридической помощи и др.

Правовое регулирование указанных форм основывается на общем международно-правовом принципе сотрудничества государств, 
являющемся одним из важнейших принципов международного права. Применительно к сфере борьбы с отмыванием доходов он означает обязанность участников Конвенции в максимально возможной степени сотрудничать друг с другом в целях проведения расследований и разбирательств, направленных на конфискацию орудий преступной деятельности и доходов от нее (п.1.ст.7 Страсбурской конвенции).

Одной из основных форм международного сотрудничества в сфере борьбы с отмыванием преступных доходов является взаимная правовая помощь в расследовании, уголовном преследовании и судебном разбирательстве, включающая в себя также обмен информацией между компетентными органами государств.

По общему правилу, взаимная юридическая помощь предоставляется только на основе письменного запроса. В то же время Страсбургская конвенция предусматривает возможность оказания помощи в определенных случаях и при отсутствии запроса со стороны другого государства. Так, ст.10 Конвенции гласит: «Без ущерба для собственного расследования или разбирательства, Сторона может без предварительного запроса передать другой Стороне информацию об орудиях и доходах, когда она считает, что предоставление такой информации может помочь Стороне-получателю в возбуждении или проведении расследования или разбирательства» либо может привести к направлению этой Стороной запроса о помощи в проведении расследования. Данное положение существенно облегчает оперативный обмен информацией между национальными полицейскими учреждениями.

Конвенция предусматривает также возможность взаимной передачи материалов уголовного разбирательства, что может осуществляться по соглашению между сторонами в интересах надлежащего отправления правосудия.

Другим важнейшим направлением международного сотрудничества является взаимодействие в сфере конфискации преступных доходов, регулированию которого уделено основное внимание в Страсбургской конвенцин.

Так, в соответствии с п. «d» ст. 1 конфискация означает «наказание или меру, назначенную судом в результате разбирательства по уголовному делу или уголовным делам и состоящую в лишении имущества».

Как и в сфере взаимной правовой помощи, сотрудничество в сфере конфискацин осуществляется на основании запросов компе 
тентных органов государств. Такие запросы могут быть направлены на осуществление двух форм конфискации:

- конфискацию доходов или конкретного имущества, полученных в результате отмывания денег, или собственности, стонмость которой соответствует таким доходам или имуществу, а также орудий преступления;

- конфискацию иной собственности, если в нее были конвертированы такие доходы или имущество.

Страсбургская Конвенция предусматривает также две разновидности запросов о конфискации. В первом случае запрашивающая сторона, обладающая юрисдикцией над соответствующим преступлением, направляет запрашиваемой стороне просьбу о конфискации доходов или имущества от этого преступления. Запрашиваемая сторона передает запрос свонм компетентным органам с целью получения постановления о конфискации и в случае выдачи такого постановления приводит его в исполнение. Во втором случае запрашивающая сторона направляет вместе с просьбой постановление о конфискации, вынесенное ее национальными органами, которое подлежит исполнению запрашиваемой стороной.

В любом из этих случаев, согласно ст.11 Страсбургской конвенции, запрашивающее государство, возбудившее уголовное преследование или разбирательство в целях конфискации, может просить запрашиваемое государство принять в отношении имущества, подлежащего конфискации, необходимые меры обеспечения, такие как замораживание или арест имущества, с тем чтобы предотвратить любые операции с имуществом вплоть до его конфискации. Просьба о принятии такнх мер может направляться также до запроса о конфискации. Получив соответствующую просьбу о принятии мер обеспечения, запрашиваемое государство обязано ее удовлетворить.

Международное сотрудничество в сфере конфискации осуществляется исключительно в рамках национального законодательства запрашиваемого государства. При этом согласно ст.16 Конвенции запрос о конфискации не затрагивает права запрашиваемой стороны самой исполнить постановление о конфискации.

Определенную проблему, на наш взгляд, представляют собой положения Конвенции, касающиеся судьбы конфискуемого имущества. Ст. 15 предусматривает право запрашиваемой стороны «распоряжаться любым конфискованным ею имуществом в соответствии со своим внутренним законодательством, если только соответствующие Стороны не договорятся об ином». Вполне очевидно, что это поло- 
жение может оказывать стимулируюшее влияние на решение запрашиваемой стороны о конфискации, так как конфискуемое имущество остается в ее распоряжении. В то же время запрашивающая сторона заинтересована в возвращении в ее экономику денежных средств или иного имущества, изъятых в результате совершения преступления. Учитывая то, что обычно лишь часть конфискованных средств возвращается в страну происхождения, сторона может не обращаться с запросом о конфискации, рассчитывая осуществить ее на своей территории. Однако в этом случае операции по отмыванию могут успешно завершиться, и имущество останется в распоряжении преступных организаций.

Представляется, что наиболее приемлемые варианты распределения конфискованного имущества могли бы быть определены общим соглашением о его разделе, например в виде Дополнительного протокола к Страсбургской конвенции, что послужило бы еще одним стимулом $K$ международному сотрудничеству государствучастников в отношении конфискации доходов от отмывания денег.

В Страсбургской конвенции предусмотрена и возможность omказа от сотрудничества. Этот вопрос является наиболее сложным в международно-правовых отношениях, поскольку он непосредственно касается суверенитета того или иного государства. Основания отказа предопределяются прежде всего необходимостью сохранения за государствами их суверенных прав, в том числе права исключительной юрисдикции на собственной территории.

В ст. 18 Страсбургской конвенции приводится широкий перечень оснований для отказа в сотрудничестве. Так, во взаимодействии может быть отказано, если правонарушение, в связи с которым сделан запрос, не является преступлением по законодательству запрашиваемой стороны. Невозможность принятия соответствующих мер при расследовании или судебном разбирательстве аналогичного дела по внутреннему праву может выступать основанием для отказа запрашиваемой стороны в принятии мер обеспечения. Далее, в конфискации может быть отказано, если законодательство запрашиваемой стороны не предусматривает возможность ее осуществления в связи с основными видами правонарушений, в отношении которых сделан запрос.

Помимо того, в соответствии со ст.18, в сотрудничестве может быть отказано, если:

- запрос противоречит основным принципам правовой системы запрашиваемой стороны; 
- запрашиваемая сторона считает, что дело, в связи с которым сделан запрос, не является достаточно важным для того, чтобы оправдать осуществление запрашиваемого действия;

- исполнение запроса может нанести ущерб суверенитету, безопасности, общественному порядку или другим существенным интересам запрашиваемой стороны;

- запрос сделан в связи с политическим или фискальным правонарушением;

- запрашиваемая сторона считает, что удовлетворение запроса противоречит принципу ne bis in idem.

По существу, все приведенные основания сводятся к одному главному препятствию для международного сотрудничества - различиям во внутригосударственных правовых нормах. Страсбургская конвенция, как следует из вышесказанного, не устраняет в целом этих различий, хотя и поощряет их упразднение. Таким образом, в полном соответствии с Конвенцией может сложиться ситуация, когда государства-участники в силу расхождений в их национальном праве смогут правомерно отказаться от сотрудничества, нисколько не нарушая своих международных обязательств. При таких обстоятельствах положения Конвенции в этой части останутся нереализованными.

Страсбургская конвенция закрепляет многочисленные возможности для отказа в сотрудничестве, в то же время провозглашая общей целью их устранение и унификацию национальных законодательств государств-участников, имеет свое объяснение.

Международное сотрудничество государств в любой сфере развивается постепенно. Первоначально государства, как правило, еще не готовы принимать на себя обширные международно-правовые обязательства и вследствие этого стремятся их ограничить. В то же время на последующих этапах, вместе с дальнейшим осознанием государствами важности сотрудничества в этой сфере и проявлением определенных положительных результатов от взаимодействия, происходит постепенная отмена ограничений и активизация сотрудничества. При этом на всех этапах государства провозглашают стремление ко все более интенсивному взаимодействию.

Такая тенденция в полной мере характерна и для международного сотрудничества в сфере борьбы с отмыванием денег. Страсбургская конвенция, относящаяся к начальному этапу, действительно еще содержит значительные препятствия международному взаимо- 
действию. В то же время развитие сотрудничества будет, как представляется, связано с поэтапной отменой указанных ограничений.

Помимо сотрудничества, предусмотренного многосторонними международно-правовыми актами, взаимодействие в области противодействия отмыванию доходов осуществляется также в рамках других международно-правовых договоренностей. К ним относятся, главным образом, двусторонние соглашения об оказании взаимной правовой помощи, о сотрудничестве в области борьбы с преступностью, о взанмной выдаче преступников. За последние годы отмечается заключение специальных двусторонних соглашений, направленных на борьбу с незаконным оборотом наркотиков и отмыванием денег.

Наряду с этим, отдельные положения о противодействии легализации преступных доходов включаются в общие рамочные двусторонние соглашения.

В течение истекшего десятилетия сотрудничество государств и международных организаций в целях противодействня легализации (отмыванию) доходов развивалось сравнительно быстрыми темпами как в рамках организаций с широкой компетенцией (например, Совет Европы, ЕС), так и через специальные органы, созданные для борьбы с отмыванием денег, в частности ФАТФ (Financial Action Task Force on Money Zoundering).

Роль международной специальной Финансовой комиссии по проблемам отмывания денег (ФАТФ)

Международная Финансовая комиссия по проблемам отмывания денег была учреждена по инициативе семи ведущих индустриальных стран и президента Комиссии Европейских Сообществ во время встречи на высшем уровне в июле 1989 г. в Париже.

В ФАТФ входит около 30 государств, в том числе Австрия, Бельгия, Дания, Финляндия, Франция, Германия, Исландия, Ирландия, Нталия, Норвегия, Португалия, Испания, Люксембург, Нидерланды, Швейцария, Турция, Великобритания и др.

При обсуждении вопроса о приеме России в ФАТФ представители этой организации в первую очередь высказались за приведение российского законодательства в соответствие с нормами междуна- 
родного права, принятыми мировым сообществом в отношении финансовых преступлений ${ }^{13}$.

Деятельность ФАТФ многогранна, что очень важно для борьбы с отмыванием денег, она объединяет экспертов, определяющих политику в законодательной, экономической и правоохранительной областях, и располагает большими техническими возможностями, а ее сотрудники обладают специальными знаниями и опытом принятия решений в сфере финансов, юстиции, иностранных дел и др.

В 1990 г. были подготовлены «Сорок рекомендаций ФАТФ», которые представляют собой основные положения концепции противодействия легализации незаконных доходов. В дальнейшем они пересматривались с учетом накопленного опыта и изменений, происходящих в сфере отмывания денег.

Укажем на следующие основные рекомендации государствамучастникам:

— объявить отмывание грязных денег уголовным преступлением;

- осуществлять ряд эффективных мер с целью выявления, изъятия и конфискации «отмытых» денег;

- реализовать эффективную систему установления личности клиентов и внедрить процедуры ведения учета финансовыми учреждениями;

- внедрить практику извещения компетентных органов власти о фактах сомнительных сделок, включая отмену конфиденциальности банковских операций при возникновении подозрений в том, что в обращении находятся криминальные деньги;

- поддерживать тесное сотрудничество между государствами в осуществлении операций правоохранительного характера и оказывать взаимную помощь в уголовном и судебном разбирательстве случаев отмывания грязных денег, расследовании, изучении и конфискации легализованных незаконных доходов.

Уже в вводной части Рекомендаций государствам-участникам предлагается включить в национальные программы по противодействию легализации (отмыванию) доходов и в соответствующие нормативно-правовые акты положения, дающие возможность осуществлять многостороннее международное сотрудничество, правовую помощь и экстрадицию в связи с отмыванием денег.

${ }^{13}$ См.: Мусин Э. В Европе с «отмыванием» строго // Экономика и жизнь 1997. № 51, c. 26. 
Вопросам укрепления международного сотрудничества в борьбе с отмыванием денег, полученных незаконным путем, посвящены 30 - 40-я рекомендации.

Положения 30 - 32 «Сорока рекомендаций ФАТФ» касаются обмена информацией как общего характера, так и о конкретных подозрительных сделках. Национальным исполнительным властям рекомендуется регистрировать международные перемещения денежных средств в любом валютном выражении, чтобы после соотнесения этих сумм с информацией центрального банка иметь возможность оценить объем отправляемой за рубеж и поступающей из различных зарубежных источников наличности, и представлять эту информацию Международному валютному фонду и Банку международных расчетов.

Обмен оперативной информацией о конкретных подозрительных операциях и участвующих в них лицах, преступных организациях и финансовых учреждениях должен способствовать выявлению полицейскими органами различных государств всего комплекса финансовых операций международного характера, осуществляемых в процессе отмывания денег, обеспечить возможность своевременного возбуждения уголовных дел в каждой из стран, а при необходимости - проведение совместных действий и оказание правовой помощи. Предусматривается возможность передачи информации по запросу, а также без запроса, аналогично положениям Страсбургской конвенции.

В рекомендации 32 особо отмечается необходимость обеспечения обмена информацией в строгом соответствии с национальными и международными нормами, касающимися конфиденциальности и защиты данных. Эта проблема имеет как юридические, так и неюридические аспекты. К юридическим аспектам относится наличие или отсутствие в законодательстве государств положений, касающихся зашиты персональных данных, к неюридическим - степень коррумпированности органов полиции и юстиции, что обусловливает возможность утечки информации.

Рекомендации $33-35$ касаются «основ и средств для сотрудничества в области проведения конфискации, взаимной помощи и экстрадиции». В частности, рекомендация 33 побуждает страны посредством двустороннего или многостороннего сотрудничества принять меры к тому, чтобы различные толкование и понимание правовых норм в рамках национальных определений не оказывали негативного воздействия на возможность и добрую волю в оказании взаимной 
правовой помощи в борьбе с легализацией (отмыванием) грязных денег и иных капиталов.

Рекомендация 34 предлагает государствам расширять систему двусторонних и многосторонних договоров, регулирующих вопросы правовой помощи в борьбе с отмыванием денег. В целом эти положения Рекомендаций совпадают с нормами Венской и Страсбургской конвенций, касающихся розыска преступников и конфискации доходов.

Среди различных видов оперативно-розыскной деятельности, применяемых в этих целях, особо следует выделить контролируемое перемещение отмываемых средств (разновидность контролируемой поставки, как она определена в Венской конвенции). Рекомендация 36 всемерно поощряет использование этого метода.

Данный метод наряду с использованием оперативного внедрения справедливо оценивается как один из самых эффективных. Выявление конкретных цепочек финансовых операций по отмыванию денег до их завершения позволяет обнаружить легализуемые средства в полном объеме, а также установить их реальных владельцев, входящих, как правило, в руководство преступных организаций. Кроме того, с помощью указанных методов собирается аналитическая информация как о наиболее типичных, так и о новых формах отмывания денег, используемых в финансовых центрах и оффшорных зонах.

Согласно рекомендации 37, должны существовать процедуры оказания взаимной помощи в сфере применения уголовного права, касающегося введения принудительных мер, включая введение регистрационных записей финансовыми учреждениями и другими лицами, розыск конкретных лиц и недвижимости, изъятие и получение доказательств для использования на территории иностранной юрисдикции в ходе расследований, предпринимаемых в отношении отмываемых денег.

Рекомендация 38 нацелена на то, чтобы у соответствующих органов имелись полномочия в ответ на просьбу других стран предпринимать неотложные меры по выявлению, замораживанию, изъятию и конфискации доходов или другой собственности, равной по своей стоимости доходам, которые получены в результате отмывания денег или в ходе преступных действий, включающих отмывание денег. Должны также существовать договоренности о координации судебных разбирательств по вопросам изъятия и конфискации, в ходе которых возникают проблемы с разделением подлежащего конфискации имущества. 
Рекомендация 40 предлагает государствам включить в национальное законодательство положения, позволяющие осуществлять выдачу лиц, совершивших преступления, связанные с отмыванием денег. При этом государства, с учетом основных принципов их правовых систем, могут рассмотреть возможность упрощения процедуры выдачи, в частности, путем:

- непосредственного направления просьб о выдаче через уполномоченные министерства;

- признания в качестве достаточного основания для экстрадиции ордера на арест или судебного решения запрашивающего государства;

- осуществления выдачи запрашиваемым государством своих граждан;

- введения ускоренной процедуры выдачи в отношении лиц, отказывающихся от применения к ним формальностей, связанных с экстрадицией.

ФАТФ с самого начала своего существования исходила из того положения, что стороны имеют различные законодательные и финансовые системы и потому не в состоянии использовать одинаковые способы борьбы с отмыванием денег. Поэтому рассмотренные рекомендации предложены лишь в качестве принципов работы в этой сфере, которые каждая сторона должна внедрять в соответствии со своими конкретными обстоятельствами и конституционной системой. Таким образом, стороны получают свободу действия, а не подробные предписания. Эти меры не являются чрезмерно сложными или трудными при условии реального желания добиться успеха. Равным образом они не оказывают негативного воздействия на свободу проведения легальных финансовых операций и не создают угрозу экономическому развитию.

Страны - члены ФАТФ заявили о безусловном согласии на проведение многостороннего контроля и детального анализа ситуации, складывающейся в результате деятельности других участников на своей территории. Все страны-участницы используют двусторонний подход для контроля реализации рассматриваемых рекомендаций: проведение ежегодной самооценки и осуществление более детального взаимного контроля; в ходе которого предусмотрена инстанция на месте. В дополнение к этому ФАТФ проводит в различных странах сравнительное изучение мер, принятых для реализации конкретных рекомендаций. 
В настоящее время деятельность ФАТФ осуществляется в четыpeх основных сферах ${ }^{14}$ :

- проверка соблюдения рекомендаций ФАТФ ее членами;

- обзор новых методов и типологий отмывания денег;

- обеспечение выполнения рекомендаций государствами членами ФАТФ;

- сотрудничество с другими международными организациями.

Кроме того, ФАТФ проводит специальные исследования имеющих место и могущих возникнуть в будущем методов (типологий) отмывания денег в целях содействия их выявлению компетентными органами государств и ежегодные деловые встречи экспертов правоохранительных органов для обсуждения наметившихся за истекший год тенденций в сфере отмывания денег. По результатам работы специалистов готовятся специальные доклады о типологиях легализации (отмывания) денег (money laundering typologies reports), которые являются авторитетными источниками сведений о способах и методах легализации доходов, полученных незаконным путем. В итоге в них обобщается наиболее важная информация, предоставленная государствами-участниками и международными организациями в сфере борьбы с отмыванием денег.

Еще одно из направлений деятельности ФАТФ заключается в анализе положения дел с реализацией сорока рекомендаций государствами, не являющимися ее членами. Это объясняется тем, что многие основные центры по отмыванию капиталов, нажитых преступным путем, расположены за пределами юрисдикции рассматриваемой организации. Таким образом, ставится задача привлечь к активной борьбе с отмыванием денег как можно большее число государств. С этой целью в 1999 г. создана экспертная группа ad hoc, представившая в феврале 2000 г. Отчет о не участвующих в сотрудничестве странах и территориях (Report on non-cooperation countries and territories). Основные его идеи заключаются в том, что ФАТФ должна активизировать свою деятельность по распространению принципов, содержащихся в ее сорока рекомендациях, во всем мире.

Осуществление предусмотренных в Рекомендациях в общем-то несложных мероприятий требует лишь одного - политической воли высшего руководства. Кроме того, реализация этих мероприятий не

${ }^{14}$ См.: The globalization fight against money laundering: remarks by Patrick Moulette. Executive secretary of the FATF; FATF/BSEC Seminar on Money laundering, Athens, 21-22 October 1998, а также: FATF annual report, 1998-1999. 
представляет никакой угрозы для экономического развития той или иной страны и не ставит под сомнение свободу осуществления законных сделок.

Российское законодательство о противодействии легализации (отмыванию) доходов, получениых незаконным путем

Международное и европейское право становится все более значимым для России, вступившей в Совет Европы и постоянно расширяющей свои деловые экономические и политико-правовые контакты с государствами Европейского Союза.

7 мая 1999 г. в Будапеште от имени Российской Федерации подписана под условием последующей ратификации рассмотренная выше Конвенция об отмывании, выявлении, изъятии и конфискации доходов от преступной деятельности (Страсбургская конвенция). Участие России в Конвенции предусмотрено обязательствами, взятыми нашей страной при вступлении в Совет Европы, и может стать важным шагом на пути дальнейшей интеграции Российской Федерации в европейские правовые структуры.

Конвенция содержит правила несколько иные, чем предусмотренные действующим уголовным законодательством России (ст. 174 Уголовного кодекса РФ), поэтому на основании п. 1 «а» ст. 15 Федерального закона «О международных договорах Российской Федерации» от 16 июня 1995 г. она подлежит ратификации ${ }^{15}$.

С учетом вышеизложенного, участие России в Конвенции потребует внесения соответствующих изменений в уголовное и уголовно-процессуальное законодательство Российской Федерации ${ }^{16}$. Впрочем, этого требуют и объективные обстоятельства. За последние годы в России все очевиднее первоочередной становится проблема нелегального капитала - проблема, имеющая экономические, социально-политические, правовые и иные аспекты. Сформировавшийся в России социальный слой владельцев средней и крупной собственности в немалой малой степени скрывает эту собственность от официального учета и контроля со стороны государства и обще-

is См.: Комментарий к Федеральному закону «О международных договорах Российской Федерации». М., 1996.

${ }^{16}$ См., например: Алиеб. В.М., Болотский Б.С. Указ. соч., с.44-50. 
ства. Нелегальный капитал изъят из официального оборота, а во многих случаях эмигрирует за границу.

Соответствующее уголовное наказание предусмотрено ст. 174 УК РФ «Легализация (отмывание) денежных средств или иного имущества, приобретенных незаконным путем». Она гласит:

«1. Совершение финансовых операций и других сделок с денежными средствами или иным имуществом, приобретенными заведомо незаконным путем, а равно использование указанных средств или иного имущества для осуществления предпринимательской или иной экономической деятельности - наказывается штрафом в размере от пятисот до семисот минимальных размеров оплаты труда или в размере заработной платы или иного дохода осужденного за период от пяти до семи месяцев либо лишением свободы на срок до четырех лет со штрафом в размере до ста минимальных размеров оплаты труда или в размере заработной платы или иного дохода осужденного за период одного месяца либо без такового.

2. Те же деяния, совершенные:

а) группой лиц по предварительному сговору;

б) неоднократно;

в) лицом с использованием своего служебного положения - наказывается лишением свободы на срок от четырех до восьми лет с конфискацией имущества или без таковой.

3. Деяния, предусмотренные частями первой или второй настоящей статьи, совершенные организованной группой или в крупном размере, наказываются лишением свободы на срок от семи до десяти лет с конфискацией имущества или без таковой» 17 .

Прежде всего следует обратить внимание, что данная норма Уголовного кодекса РФ предусматривает уголовную ответственность за отмывание доходов, полученных не только преступным путем (т.е. в результате преступления), но и извлеченных незаконным образом - например, в рамках административного правонарушения.

Такое толкование находит свое подтверждение и в Постановлении Правительства Российской Федерации от 8 июня 1997 г. № 840, которым утверждено Типовое соглашение между Правительством Российской Федерации и Правительством иностранного государства о сотрудничестве и взаимной помощи в области борьбы с незакон-

${ }^{17}$ Полное собрание кодексов РФ. М., 2000, с. 213-214. 
ными финансовыми операциями, связанными с легализацией (отмыванием) доходов, полученных незаконным путем ${ }^{18}$.

Ст. 1 Типового соглашения гласит: «Доходы, полученные незаконным путем» - вещи, включая деньги и ценные бумаги, движимое и недвижимое имущество, имущественные права, работа и услуги, результаты интеллектуальной деятельности, в том числе исключительные права на них (интеллектуальная собственность), иные объекты гражданских прав, приобретенные в результате нарушения национального законодательства каждой из сторон, влекущего за собой уголовную, административную или гражданскую ответственность».

Указанная и другие нормы были воспроизведены в ряде двусторонних соглашений Правительства России с зарубежными странами ${ }^{19}$.

Поскольку формулировка «легализация (отмывание) имущества, приобретенного незаконным путем», закрепленная в ст. 174 УК РФ, должным образом не определена, специалисты высказывают различные суждения относительно юридической сущности понятия «незаконный путь приобретения имущества».

В широком лексико-правовом смысле «незаконный» означает: вопреки закону, не в соответствии с законом, в противоречии с законом и Т.д.

В этом контексте требуется ответ законодателя на вопрос, какому именно закону должно не соответствовать деяние, квалифицируемое по ст. 174 УК РФ (уголовному, административному, гражданскому или какому-либо иному)?

По смыслу этой статьи, видимо, следует считать, что незаконность в данном случае заключается в нарушении уголовно-правового запрета, иначе применение рассматриваемой статьи УК будет само по себе противоправным в силу п. 2 ст. 14 УК РФ («Понятие преступления») ввиду отсутствия общественной опасности деяния. В этой статье речь идет о том, что «не является преступлением действие (бездействие), хотя формально и содержащее признаки какого-либо деяния, предусмотренные настоящим Кодексом, но в силу малозначительности не представляющие общественной опасности» ${ }^{20}$, то есть не причинившие вреда и не создавшие угрозы причинения вреда личности, обществу и государству.

${ }^{18}$ См.: Собрание законодательства РФ. 1997, № 28, ст. 3471.

${ }^{19}$ См.: Aлиео В.M., Болотскии Б.(: Указ соч., с. 48-49.

2) Полное собрание кодексов РФ, с.191. 
Для состава преступления, предусмотренного ст. 174 УК РФ, не является обязательным знание виновным того, в результате какого именно преступления добыто имущество, кто и при каких обстоятельствах его совершил. Однако необходимо установить заведомое знание субъектом того, что он легализует денежные средства или имущество, приобретенные преступным путем. Об этом могут свидетельствовать различные объективные обстоятельства: вид имущества, его количество и стоимость, время и место совершения сделки и т.д.

Состав преступления является формальным и деяние считается оконченным в момент совершения любого из действий, указанных в рассматриваемой статье.

Часть 2 ст. 174 УК РФ содержит три квалифицирующих признака преступления: а) группой лиц по предварительному сговору; б) неоднократно; в) лицом с использованием своего служебного положения.

Предварительный сговор может касаться отдельных моментов (эпизодов) совершения преступления, не образуя прочных связей между соучастниками, или представлять собой высокую степень согласованных действий.

Неоднократность преступлений квалифицируется ст. 16 УК РФ и предполагает совершение одним лицом или группой лиц не менее двух преступлений.

Совершение лицом (группой лиц) двух или более преступлений предполагает, что каждое из них имеет характер отдельного, единичного преступления. При этом не имеет значения, окончено ли каждое из них или нет, в какой роли выступал виновный - исполнителя, организатора, подстрекателя, пособника.

Преступление не признается совершенным неоднократно, если за ранее совершенное преступное деяние лицо было в установленном законом порядке освобождено от уголовной ответственности либо судимость за совершенное ранее преступление была погашена или снята.

Под действием, совершенным с использованием служебного положения, необходимо понимать такие действия лица, которые не выходят за пределы его функциональных обязанностей, но направлены против общественных интересов.

Размер ущерба, трактуемого в ст. 174 УК РФ как кругный, отнесен к категории оценочных прнзнаков.

В то же время необходимо отметить, что определение состава преступления по отмыванию капиталов, закренленное і ст. ! 4 УК 
РСФСР, не совсем соответствует положениям Конвенции Совета Европы об отмывании, выявлении, изъятии и конфискации доходов от преступной деятельности 1990 г., т.к. предусматривает уголовную ответственность только за деяния в виде финансовых операций, преступных и иных незаконных сделок с имуществом, а также использование незаконных средств для предпринимательской или иной экономической деятельности ${ }^{21}$. Совершение других деяний с денежными средствами и иным имуществом остается за пределами действия этой уголовно-правовой нормы. Однако конкретные правонарушения могут квалифицироваться и по другим нормам УК РФ, а именно по ст. 175 («Приобретение или сбыт имущества, добытого заведомо преступным путем»); при наличии признаков соучастия cт. 34 («Соучастие»), ст. 35 («Совершение преступления группой лиц, группой лиц по предварительному сговору, организованной группой или преступным сообществом») с одновременной квалификацией по соответствующим нормам Особенной части УК, предусматривающим ответственность за преступления, в результате которых был получен незаконный доход (например, ст. 228 «Незаконные изготовление, приобретение, хранение, перевозка, пересылка либо сбыт наркотических средств или психотропных веществ». В последнем случае российское уголовное законодательство исходит из того, что деяние соучастника, выразившееся в легализации незаконного дохода, представляет общественную опасность в силу того, что оно причинно и виновно связано с основным преступлением, в результате совершения которого получен противоправный доход.

Различные аспекты борьбы с незаконными доходами регламентируются нормами отдельных законодательных актов.

В соответствии с Федеральным законом РФ «О Центральном банке Российской Федерации (Банке России)» от 8 июля 1999 r. $^{22}$ Банк России осуществляет надзор за соблюдением банковского законодательства, может назначать и осуществлять проверку операций банков, поручать проведение таких проверок аудиторским организациям. Также Банк России вправе давать банкам обязательные для исполнения предписания об устранении нарушений законодательства Российской Федерации о банках. В случае неисполнения предписаний Банка Рос-

21 См. также: Российское уголовное право. Особенная часть / Под ред. В.Н. Кудрявцева, А.В. Наумова. М., 1997, с. 187; Комментарий к Уголовному кодексу Российской Федерации. М., 1997, с. 405-406.

22 См.: Российская газета, 1999, 14 июля. 
сии, а также при выявлении нарушений нормативов, причинивших ущерб банкам и клиентам, непредставления отчетности или представления недостоверной или вводящей в заблуждение отчетности, при обнаружении других систематических нарушений Банк России вправе предъявить требовании, в частности, о реорганизации банка, о замене руководителей банка, а таюже имеет право назначить временную администрацию по управлению банком или применить иные меры вплоть до отзыва лицензии на совершение банковских операций, что действует как решение о ликвидации банка.

Закон РФ «О банках и банковской деятельности» от 2 декабря 1990 г. в редакции от 3 февраля 1996 г. и от 8 июля 1999 г. $^{23}$ содержит перечень операций и сделок, которые рассматриваются в качестве банковских и, соответственно, требуют наличия банковской лицензии, выдаваемой Центральным банком. Закон регулирует общие вопросы наложения ареста и обращения взыскания на денежные средства и другие ценности, находящиеся в банках; устанавливает перечень органов, имеющих право на совершение указанных действий (суды общей компетенции, арбитражные суды, следственные органы, а также финансовые и другие органы в случаях, прямо предусмотренных законодательством Российской Федерации. Регламентируются вопросы обеспечения банковской тайны, а также возможные случаи ее ограничения по решению или приговору суда, по мотивированному постановлению следственных органов и т.д.

Ряд положений, направленных на борьбу с отмыванием денег, содержится в законах «Об иностранных инвестициях в Российской Федерации» от 9 июля 1999 г. $^{24}$, «О валютном регулировании и валютном контроле) от 9 октября 1991 г. (в редакции от 29 декабря 1998 г. и от 5 июля 1999 г. $)^{25}$, «Об основах налоговой системы в Российской Федерации» от 27 декабря 1991 г. (в ред. от 5 августа 2000 г. $)^{26}$, «О конкуренции и ограничении монополистической деятельности на товарных рынках» от 22 марта 1991 г. (в ред. от 2 января 2000 г.) $)^{27}$.

\footnotetext{
${ }^{23}$ См.: Российская газета, 1996, 10 февраля; 1999, 14 июля.

${ }^{24}$ См.: Собрание законодательства РФ. 1999, № 28, ст. 3493.

${ }^{25}$ См.: Ведомости СНД РФ и ВС РФ. 1992, № 45, ст. 2542.

${ }^{26}$ См.: Российская газета, 1992, 10 марта; 2000, 10 августа.

${ }^{27}$ См.: Ведомости СНД РФ и ВС РФ. 1991, № 16, ст. 4999; Российская плета. 2000,5 января.
} 
В действующем законодательстве имеются определенные механизмы контроля за доходами, полученными в результате преступной деятельности.

Прежде всего эффективной мерой в этой области призваны стать положения Закона РФ «О налоговых органах Российской Федерации» (в ред. от 8 июня 1994 г.) ${ }^{28}$, в соответствии с которыми государственным налоговым инспекциям предоставлено, в частности, право:

- производить проверки денежных документов, бухгалтерских книг, отчетов, планов, смет, деклараций и иных документов, связанных с исчислением и уплатой налогов и других обязательных платежей в бюджет; получать необходимые объяснения, справки и сведения по вопросам. возникающим при проверках, за исключением сведений, составляющих коммерческую тайну ${ }^{29}$;

- приостановить операции предприятий, учреждений, организаций и граждан по расчетным и другим счетам в банках и иных финансово-кредитных учреждениях в случае непредставления (или отказа представить) государственным налоговым инспекциям и их должностным лицам бухгалтерских отчетов, балансов, расчетов, деклараций и других документов, связанных с исчислением и уплатбй налогов и иных обязательных платежей в бюджет;

- изымать у предприятий, учреждений и организаций документы, свидетельствующие о сокрытии или занижении прибыли (дохода) или о сокрытии иных объектов от налогообложения, с одновременным производством осмотра документов, фиксации их содержания;

- контролировать соблюдение законодательства гражданами, занимающимися предпринимательской деятельностью;

${ }^{28}$ См.: Бюллетень нормативных актов. 1992, № 1; Российская газета, 1999, 14 июля.

29 Перечень сведений, которые не могут составлять коммерческую тайну, содержится в Постановлении Правительства Российский Федерации от 5 декабря 1991 г. (учредительные документы и Устав; документы, дающие право заниматься предпринимательской деятельностью (регистрационные удостоверения, лицензии, патенты); сведении по установленным формам отчетности о финансово-хозяйственной деятельности и иные сведения, необходимые для проверки правильности исчисления и уплаты налогов и других обязательных платежей; документы п платежеспособности; сведения о численности, составе работающих, нх заработной плате и условиях труда; документы об уплате налогов и обязательных платежах; сведения об участии должностных лиц в других орғанизациях, занимающихся предпринимательской деятельностью. 
- обследовать с соблюдением соответствующих правил при осуществлении своих полномочий любые используемые для извлечения доходов либо связанные с ним объекты налогообложения независимо от места их нахождения, производственные, складские, торговые и иные помещения предприятий, организаций и граждан;

- предъявлять в суде или арбитражном суде иски: о признании сделок недействительными и взыскании в доход государства всего полученного по таким сделкам; о взыскании неосновательно приобретенного не по сделке, а в результате других незаконных действий.

Механизм контроля за доходами и крупномасштабными операциями с денежными средствами осуществляют также федеральные органы налоговой полиции (Закон РФ «О федеральных органах налоговой полиции» от 24 июня 1993 г. в ред. от 17 декабря 1995 г.) $)^{30}$, основной функцией которых является осуществление оперативнорозыскной деятельности в целях выявления юридических и физических лиц, уклоняющихся от уплаты налогов или занижающих полученный доход, и Федеральная служба России по валютному и экспортному контролю (Указ Президента Российской Федерации «О Федеральной службе России по валютному и экспортному контролю» от 24 сентября 1993 г: и соответствующие Постановления Правительства РФ от 15 ноября 1993 г. и 3 февраля 1994 г.), в компетенцию которой входят вопросы надзора за соблюдением действующего валютного и внешнеэкономического законодательства, репатриации валютной выручки от осуществления экспортных операций, обеспечения контроля за деятельностью субъектов внешнеторгового оборота.

К числу законодательных мер, направленных, в частности, на борьбу с незаконным оборотом денежных средств, можно отнести положения Указа Президента Российской Федерации «Об осуществлении комплексных мер по своевременному и полному внесению в бюджет налогов и иных обязательных платежей» от 23 мая 1994 г. Пункт 8 данного Указа предусматривает обязанность банков и других кредитных учреждений информировать налоговые органы о совершении физическими лицами (включая нерезидентов) операций на сумму, эквивалентную 10 тысячам долларов США и выше.

В соответствии со ст. 35 Конституции России, ст.ст. 235, 243 ГК РФ в случаях, предусмотренных законодательными актами, имущество может быть изъято по решению суда или арбитражного суда в виде санкции за совершение преступления или иного правонаруше-

${ }^{30}$ См.: Российская газета, 1993, 15 июля; 1995, 27 декабря. 
ния. Таким образом, по российскому законодательству конфискация выступает в качестве меры как уголовной, так и административной ответственности.

Ст. 52 УК РФ (регулирует вопросы конфискации имущества осужденного) исходит, в частности, из того, что конфискация имущества является дополнительным наказанием и назначается судом в случаях, предусмотренных Особенной частью УК (прежде всего за корыстные преступления). Уголовно-процессуальный кодекс дает суду право, кроме назначения конфискации имущества, обращать также в доход государства являющиеся вещественными доказательствами деньги и иные ценности, нажитые преступным путем. На стадии расследования УПК предусматривает возможность наложения ареста на имущество, приобретенное преступным путем.

Гражданское законодательство предусматривает возможность взыскания в доход государства имущества, приобретенного по сделкам, признанным в установленном порядке недействительными, а также взыскания неосновательно приобретенного не по сделке, а в результате других незаконных действий (недопущение реституции). Однако правовые последствия в виде взыскания в доход государства приобретенного дохода могут иметь место только в случае «совершения сделки с целью, заведомо противной основам правопорядка и нравственности» (ст. 169 ГК РФ).

Сложившаяся в России криминальная ситуация, в том числе с отмыванием капиталов, предопределила общественную потребность комплексного решения проблемы. С одной стороны необходимо выявить ту часть нелегального капитала, не имеющего преступного характера, которая должна быть легализована и вовлечена в официальный гражданский оборот, а с другой, разработать и реализовать более жесткие формы борьбы с преступным капиталом в соответствии, в частности, с положением норм европейского и международного права. 